\title{
POLITIK ANGGARAN: ALOKASI DANA BANSOS PRA-PEMILIHAN PRESIDEN 2019 DI INDONESIA SEBAGAI ALAT MENINGKATKAN ELEKTABILITAS
}

\author{
Muchammad Iqbal Firmansyah., Fajar Rahmanto, dan Titin Purwaningsih \\ Master of Government Affairs and Administration, Universitas Muhammadiyah Yogyakarta, Indonesia \\ E-mail: firmansyahiqbal48@gmail.com,fajarrahmanto1@gmail.com, titin.p.widodo@gmail.com
}

\begin{abstract}
ABSTRAK. Artikel ini bertujuan untuk mengetahui apakah peningkatan alokasi dana bantuan sosial oleh pemerintah pada waktu pra-pemilihan presiden berbanding lurus dengan peningkatan elektabilitas calon incumbent. Metode yang digunakan adalah kualitatif deskriptif dengan pendekatan studi kepustakaan (literature) untuk memperoleh data dan informasi penelitian. Hasil penelitian menunjukkan alokasi anggaran bantuan sosial mengalami peningkatan mendekati pemilihan presiden tahun 2019. Peningkatan belanja bansos secara bertahap dari 2016 sebesar 49,06 Triliun menjadi 58,96 Triliun tahun 2017 dan meningkat menjadi 83,91 Triliun pada 2018. Anggaran untuk program sosial juga mengalami kenaikan dari tahun 2016 sebesar 10,5 Triliun menjadi 14,09 Triliun pada 2017 dan semakin meningkat lagi pada 2018 dengan besaran 18,67 Triliun. Meningkatnya alokasi anggaran tersebut berbanding lurus dengan tingginya elektabilitas dari Jokowi sebagai kandidat petahana yang mencapai angka 50\% lebih, unggul atas Prabowo Subianto yang kurang dari 40\%. Ini menjadi indikasi bahwa program tersebut merupakan salah satu cara untuk meningkatkan elektabilitas Presiden Jokowi menjelang pemilihan presiden 2019. Dapat dikatakan anggaran bantuan sosial merupakan salah satu bentuk politik Pork Barrel di Indonesia karena dijadikan sebagai suatu upaya politis dari incumbent melalui pengalokasian anggaran dalam program pemerintah pusat kepada daerah dengan tujuan meningkatkan elektabilitas pada pemilihan berikutnya. Sehingga disimpulkan bahwa politik anggaran pada bantuan sosial menjadi salah satu isu strategis yang dapat dimanfaatkan oleh setiap incumbent guna meningkatkan elektabilitasnya pada periode pemilihan berikutnya.
\end{abstract}

Kata kunci: Politik Anggaran; Bantuan Sosial; Pemilu Presiden 2019; Elektabilitas

\begin{abstract}
This article aims to determine whether the increase in the allocation of social assistance funds by the government during the pre-presidential election is directly proportional to the increase in the electability of incumbent candidates. The method used is descriptive qualitative with a literature study approach to obtain research data and information. The results show that the social assistance budget allocation has increased approaching the 2019 presidential election. The increase in social assistance spending gradually from 2016 amounted to 49.06 trillion to 58.96 trillion in 2017 and increased to 83.91 trillion in 2018. The budget for social programs also increase from 10.5 Trillion in 2016 to 14.09 Trillion in 2017 and increasing again in 2018 with an amount of 18.67 Trillion. The increase in budget allocation is directly proportional to Jokowi's high electability as an incumbent candidate who reaches $50 \%$ more, ahead of Prabowo Subianto who is less than $40 \%$. This is an indication that the program is one way to increase President Jokowi's electability ahead of the 2019 presidential election. It can be said that the social assistance budget is one form of Pork Barrel politics in Indonesia because it is used as a political effort by the incumbent through budget allocation in central government programs to areas to increase electability in the next election. So it is concluded that this article aims to determine whether the increase in the allocation of social assistance funds by the government during the pre-presidential election is directly proportional to the increase in the electability of incumbent candidates.
\end{abstract}

Keywords: Budget Politics; Social Assistance; 2019 Presidential Election; Electability

\section{PENDAHULUAN}

Anggaran pada hakikatnya harus mampu memberikan jaminan sosial kepada publik karena anggaran tersebut adalah sesuatu yang dibutuhkan publik. Anggaran merupakan rencana keuangan secara periodik, disusun berdasarkan atas program yang telah disahkan dan merupakan rencana tertulis mengenai kegiatan suatu organisasi, dinyatakan secara kuantitatif dan umumnya dinyatakan dalam satuan moneter untuk periode tertentu (Habibi et al., 2018). Dinamika dalam setiap proses penentuan anggaran baik pada level pusat sampai pada tingkat lokal memiliki dinamika yang berbeda. Secara faktual berbicara di lapangan bahwa pihak elit-elit yang terlibat dalam proses politik anggaran, yang terjadi adalah bagaimana elit politik melakukan proses tawar- menawar mengenai besaran anggaran tersebut milik siapa dan kepada siapa anggaran tersebut dialokasikan. Lebih parah lagi, masih adanya praktik-praktik pemotongan anggaran publik yang disertai dengan rekayasa (mark-up) anggaran hanya untuk mengisi pundi-pundi keuangan pribadi maupun segelintir elit tertentu. Hubungan legislatif yang cenderung melakukan negosiasi, dan melobi kepentingan proyek dalam sub-program yang telah direncanakan sehingga seringkali diwarnai dengan terjadinya negosiasi anggaran publik (Wance, 2019). Politik anggaran adalah mekanisme kontrol politik antar stakeholder yang memiliki kepentingan dalam memutuskan alokasi anggaran dan pengeluaran pemerintah, yang terkait dengan penggunaan anggaran dialokasikan untuk siapa, kelompok siapa, di mana, dan kapan waktu pengalokasiannya (N. L. L. Aziz, 2016). 
Jusuf Kalla, Wakil Presiden Republik Indonesia periode 2014-2019, sepakat terhadap dugaan adanya muatan politik dalam penyaluran dana bansos dengan melihat tren kenaikan dana bansos mendekati waktu pemilihan umum baik di level nasional maupun di tingkat lokal. Salah satu penyebab dari penggunaan program hibah dan bansos untuk kepentingan aktor-aktor politik tertentu ialah sifat programnya yang populis, sehingga sering digunakan untuk kepentingan-kepentingan tertentu dalam pemilihan umum baik nasional maupun lokal (Saragintan \& Hidayat, 2016). Apalagi bagi seseorang yang diposisikan sebagai incumbent dalam pemilihan umum (Presiden, Gubernur, Bupati/Wali Kota) pada masa krusial, mengingat mereka harus berkompetisi lagi agar tidak terpental dari jabatan politisnya memiliki kecenderungan untuk melakukan tindakan "politisasi anggaran". Belanja Hibah (BH) dan Belanja Bantuan Sosial (BBS) adalah salah satu pos belanja yang dapat dipakai bagi calon incumbent untuk mendapatkan dukungan dari masyarakat pemilih (Habibi et al., 2018). Realisasi belanja pemerintah pusat untuk anggaran dana bantuan sosial (bansos) mencapai Rp. 15,1 triliun, pada Januari 2019. Berdasarkan data Kementerian Keuangan, angka ini melonjak tiga kali lipat dibandingkan periode yang sama, tahun sebelumnya. Jika dipersentase dengan bujet bansos di APBN 2019, maka anggaran yang cair pada Januari, sudah mencapai 15,59 persen dari total anggaran Rp. 97,06 triliun. Kemudian dari data APBN KiTA angka tersebut mengalami kenaikan sekitar 182,95 persen dari realisasi dana bansos, pada Januari 2018 sebesar Rp. 5,3 triliun atau hanya 6,3 persen dari dari total bujet bansos di APBN 2018 sebesar Rp. 77,3 triliun. Wakil Ketua Umum DPP Gerindra, Fadli Zon menilai kenaikan dana bansos secara drastis itu berkaitan dengan tahun politik. Ia mengatakan, biasanya pemerintah kerap mengeluarkan kebijakan populis menjelang pemilu, seperti bantuan tunai (tirto.id, 2019).

Setiap negara mempunyai tanggung jawab besar terhadap kesejahteraan masyarakatnya yang salah satunya dilakukan melalui penetapan kebijakan alokasi anggaran dan penerapan programprogram pemerintah. Permasalahan anggaran publik mendekatipemiluapabila dihubungkan dengan kajian politik memang menjadi isu yang cukup penting dalam pembahasan oleh para pakaryang membidangi kajian politik anggaran. Pelaksanaan anggaran untuk alokasi bantuan sosial perlu diwaspadai menjelang pelaksanaan pemilihan terlepas ada dan tidaknya motif politik. Hal itu disebabkan karena adanya potensi tingkat kerawanan untuk disalahgunakan dalam mendulang suara oleh salah satu kandidat yang bertarung dalam Pilpres 2019. Alasannya, dengan menggelontorkan dana bansos yang besar, tak jauh berbeda dengan money politics yang sebenarnya dilarang dalam kampanye yang selama ini dalam pengawasannya penggunaan dana bansos relatif lebih kendor daripada anggaran lainnya. Sehingga, sering dimanfaatkan menjadi peluang oleh berbagai pihak untuk kepentingan politiknya. Hal ini menjadi kekhawatiran tersendiri karena bisa jadi masyarakat nantinya diminta untuk memilih capres maupun caleg tertentu dengan "iming-iming" bansos tersebut (A. Aziz, 2019). Keberadaan anggaran bagi sektor publik memiliki peran yang sangat penting karena sebagai alat pemerintah dalam perencanaan pembangunan sosial ekonomi, menjamin kesinambungan, dan meningkatkan kualitas hidup masyarakat (Purwanto, 2016). Terjadinya pola perubahan anggaran pemerintah karena adanya aspek politik yang memiliki kecenderungan lebih berpengaruh daripada aspek ekonomi (Hastuti, 2018; Rahman, 2018).

Tingginya biaya politik dalam setiap pelaksanaan kontestasi pemilihan umum disebabkan karena adanya kebutuhan politik pencitraan yang menuntuk calon kandidat untuk memperoleh popularitas dan meningkatkan elektabilitas menjelang pelaksanaan pemilihan. Kebutuhan dana yang besar dalam persaingan kampanye politik menimbulkan masalah baru untuk memperoleh uang sebagai modal kampanye. Pada akhirnya praktek politik uang (money politic) akhirnya dijadikan alternatif pilihan menarik bagi calon kandidat. Menjelang pelaksanaan pemilihan umum baik di tingkat nasional dan pemilukada di tingkat lokal banyak diwarnai dengan praktek-praktek jual beli suara (vote buying), penyalahgunaan wewenang dan penggunaan anggaran untuk kepentingan kampanye, serta berbagai pelanggaran lainnya. Modus yang dilakukan adalah dengan meningkatkan anggaran bantuan sosial menjelang pelaksanaan pemilihan untuk menarik simpati melalui pemberian bantuan sosial sekaligus kampanye secara terselubung (Wulandari, 2012).

Istilah "money politic" merupakan suatu upaya mempengaruhi orang lain dengan menggunakan imbalan materi atau sering disebut dengan jual beli suara pada proses politik dan kekuasaan serta tindakan membagi-bagikan uang baik milik pribadi atau partai untuk mempengaruhi suara pemilih (voters) (Solihah, 2016). Bentuk dari "money politic" dilakukan melalui pemberian uang maupun barangbarang lainnya kepada masyarakat pemilih dengan tujuan untuk menarik simpati memberikan suaranya pada waktu pelaksanaan pemilihan umum. Secara garis besar berdasarkan dari uraian tersebut, money politic dapat disimpulkan sebagai suatu bentuk transaksi atau perjanjian antar dua pihak sama-sama 
memiliki kepentingan terutama pada praktik politik dimana terdapat pihak yang memberi dan pihak yang menerima sesuatu baik berupa materi maupun non-materi sesuai dengan kesepakatan perjanjian (Solihah, 2016).

Politik Pork Barrel awalnya didefinisikan sebagai suatu upaya dari politisi yang secara individu berusaha untuk mengamankan distribusi suara pribadi dalam pemilu di daerahnya (Denemark, 2000). Pork Barrel merupakan alokasi anggaran berdasarkan pada kriteria yang tidak diberikan secara penuh kepada public (Golden \& Min, 2013). Definisi lain mengenai politik Pork Barrel adalah sebuah usaha bagi anggota legislatif mendapatkan alokasi dana untuk dibawa kepada konstituen di daerahnya dengan tujuan agar konstituen mendapatkan sebuah insentif untuk kembali memilih calon tersebut sehingga meningkatkan elektabilitas di periode pemilihan berikutnya (Saragintan \& Hidayat, 2016). Berdasarkan atas beberapa definisi tersebut, politik Pork Barrel dalam penelitian ini dapat diartikan upaya-upaya politis yang dilakukan oleh calon incumbent melalui pengalokasian anggaran pada program-program pemerintah pusat kepada daerah dengan tujuan meningkatkan elektabilitas kandidat incumbent tersebut pada pemilihan periode berikutnya.

Secara perspective tujuan, kandidat calon eksekutif dapat menggunakan politik Pork Barrel sebagai usaha untuk memperoleh dukungan suara masyarakat. Politik Pork Barrel lebih sering terjadi pada pemilihan yang dilakukan dengan sistem secara langsung oleh masyarakat (mayor-council system), bukan pada sistem pemilihan melalui dukungan mayoritas anggota dewan (council-manager system) (Hessami, 2014). Calon kandidat yang berada pada posisi sebagai seorang petahana menurut John Farejohn memiliki alasan untuk melakukan politik Pork Barrel. Pertama, kepercayaan bahwa dengan membawa proyek ke daerah pemilihan akan membawa kesan atau riwayat mengenai dirinya yang telah membantu para konstituen sehingga menjadi modal yang akan bermanfaat pada waktu kampanye. Kedua, kepercayaan bahwa dengan memperhatikan konstituen dapat membantu menciptakan kesan tidak terkalahkan untuk mencegah munculnya calon lawan politik potensial yang berkualitas tinggi sekalipun. Ketiga, petahana dapat membeli kebebasan untuk mengejar undang-undang yang penting bagi mereka, atau bagi kepemimpinan mereka, dengan kemampuan untuk menyoroti proyek-proyek yang dimenangkan bagi konstituennya pada waktu pemilihan (Wilk, 2010).

Karakteristik mengenai fenomena politik Pork Barrel secara umum dapat disimpulkan, Pertama, dilakukan oleh seorang pimpinan pemerintahan utamanya dikaitkan kepada mereka yang akan menghadapi pemilihan umum agar terpilih kembali. Kedua, dilakukan menggunakan anggaran negara yang digambarkan melalui program pemerintah dan alokasi dana dari pusat ke daerah. Ketiga, bersifat regional atau konteks kewilayahan. Artinya, alokasi dana hanya bersifat membantu sekelompok masyarakat yang berada pada suatu konteks wilayah tertentu saja. Keempat, bersifat kewilayahan atau konteks spasial tertentu sehingga hanya masyarakat tertentu yang dapat menikmati hasil dari alokasi dana tersebut. Kelima, politik pork barrel tidak bersifat mengikat konstituennya untuk memilih incumbent karena tidak ada perjanjian yang dilakukan karena umumnya diberikan pada saat pra-pemilihan (Saragintan \& Hidayat, 2016).

Politik anggaran berpengaruh secara signifikan terhadap proses penyerapan anggaran oleh pihak eksekutif (Tessa, 2018). Regulasi, Perencanaan Anggaran dan Pengadaan Barang/Jasa memiliki pengaruh yang kuat dalam penyerapan anggaran yang dilakukan oleh pelaksana anggaran pada government (Ramadhani \& Setiawan, 2019). Penyerapan anggaran tidak bisa optimal karena keterlambatan pengesahan anggaran yang dilakukan serta adanya tarik ulur kepentingan politik antara legislative dan eksekutif dalam penetapan anggaran (Rezeki \& Hasanuddin, 2017) democratic rights and freedom of expression have been key issues in discourses surrounding EU, ÄîTurkey relations. Discussions on these questions often centre on state censorship and legislative constraints. The role of the media themselves, however, and the deeply-ingrained elements and historically-contingent norms and practices within public culture that shape the public sphere, have received a significantly lower level of attention. Despite recent legislative changes towards greater freedom of expression, major hurdles that limit democratic rights and freedoms persist in practice, as highlighted by the judicial trial (and the subsequent murder in January 2007. Kejelasan mengenai bentuk kebijakan akan memberikan kemudahan bagi pemerintah dalam melakukan pengawasan terhadap bagaimana para anggota dewan mempersiapkan proses alokasi anggaran untuk setiap pembangunan yang direncanakan (Murhaban \& Munandar, 2019). Problematika terkait anggaran merupakan persoalan yang tidak bisa dilepaskan dari kepentingan politik dari para elit dan penguasa untuk bersaing dalam memperebutkan kepentingan (N. L. L. Aziz, 2016). Pada sektor publik, anggaran merupakan dokumen politik yang berbentuk komitmen eksekutif dan kesepakatan legislative dalam menggunakan dana public untuk mencapai kepentingan tertentu sehingga lebih memiliki kecenderungan sebagai alat politik (Habibi et al., 2018). Dengan demikian politik anggaran 
dalam penelitian ini adalah kebijakan politik yang diambil pemerintah untuk mengalokasikan dan mendistribusikan anggaran dalam APBN guna mewujudkan suatu tujuan tertentu yang telah ditetapkan.

Proses perencanaan dan penilaian anggaran sektor publik adalah proses yang sangat sangat sulit karena memerlukan keterampilan manajerial serta kekuatan politik, lobi-lobi, pembangunan koalisi, pengalaman negosiasi dan mengetahui konsep dasar keuangan manajerial sektor publik sangat dibutuhkan (Laksono, 2017). Dalam perencanaan anggaran oleh eksekutif dan legislatif di tingkat lokal lebih dominan pada tahap pembahasan rencana anggaran di setiap komisi, yang biasanya menunjukkan bahwa dominasi legislatif lebih kuat ketika berlangsungnya proses pembahasan anggaran (Wance, 2019). Sebaliknya ketika dalam dinamika politik saat pembahasan anggaran didominasi oleh eksekutif maka akan berdampak terhadap tidak terakomodirnya usulan legislative (Zulfikar \& Effendi, 2018). Ada pertimbangan yang perlu diperhitungkan dalam melakukan penyusunan anggaran, yaitu kejelasan iuran, kinerja (kesesuaian harga) dan anggaran untuk tahun sebelumnya (Mentang et al., 2020).

Study empiris yang terkait dengan kajian mengenai politik anggaran telah banyak dilakukan sebelumnya. Studi penelitian yang dilakukan oleh Tessa (2018) menunjukkan hasil bahwa politik anggaran memiliki efek besar pada penyerapan anggaran oleh (eksekutif) pelaksana anggaran (Tessa, 2018). Kemudian penelitian lainnya yang dilakukan oleh Zulfikar dan Efendi (2018) menemukan bahwa dalam dinamika politik yang terjadi pada saat pembahasan anggaran didominasi oleh eksekutif maka akan berdampak terhadap tidak terakomodirnya usulan legislative (Zulfikar \& Effendi, 2018). Penelitian yang dilakukan Nugraheni dan Hidayat (2018) menyatakan bahwa ketidaksesuaian antara anggaran dan realisasi dalam urusan wajib dan urusan pilihan dipengaruhi oleh kebijakan publik dan kepentingan politik (Nugraheni \& Hidayat, 2018).Sementara itu, studi penelitian dari Habibi (2018) menunjukkan adanya indikasi calon petahana terhadap tren peningkatan belanja hibah dan belanja bantuan sosial untuk menarik minat pemilih menjelang pemilihan (Habibi, 2018).

Melihat dari studi penelitian terdahulu terkait dengan politik anggaran menarik untuk dikaji lebih dalam mengenai bagaimana politik anggaran pada alokasi penganggaran dana bansos yang dilakukan pemerintah ketika menjelang pemilihan umum. Penganggaran dana bansos merupakan senjata bagi pasangan petahana dalam meraih suara dari masyarakat dan meningkatkan elektabilitas pra-pemilihan presiden 2019. Penulisan artikel ini bertujuan untuk mengetahui apakah alokasi dana bantuan sosial oleh pemerintah mempengaruhi elektabilitas calon incumbent pada waktu pra-pemilihan presiden 2019. Sebuah hal yang bukan rahasia lagi apabila belanja dana bantuan sosial selalu meningkat apalagi mendekati waktu pemilu. Sumber kajian dalam tulisan ini dari berbagai studi pustaka, penelitian terdahulu dan juga berbagai tulisan yang terkait dengan politik anggaran. Peran politik anggaran yang sehat dan berkeadilan diharapkan mampu memberikan kontribusi penuh dalam berbagai pembangunan sektor publik sehingga pada akhirnya dapat mendorong terus berkembangnya potensipotensi dan meningkatkan kesejahteraan seluruh lapisan masyarakat.

\section{METODE}

Metodepenelitiandalampaperinimenggunakan metode kualitatif deskriptif dengan pendekatan studi kepustakaan untuk memperoleh data dan informasi penelitian. Penelitian kualitatif adalah prosedur penelitian yang menghasilkan data deskriptif berupa kata-kata tertulis (Moleong, 2012), sedangkan pendekatan studi pustaka merupakan cara untuk memperoleh informasi penelitian yang berasal dari buku, internet yang terkait erat dengan fokus kajian penelitian (Farida, 2019). Dengan menggunakan data penelitian yang bersifat deskriptif, maka tulisan paper ini dapat memberikan gambaran mengenai bagaimana alokasi anggaran hibah bansos yang dilakukan pemerintah ketika menjelang pemilihan presiden 2019. Alasan peneliti menggunakan metode penelitian kualitatif karena berkaitan dengan fokus penelitian yakni bertujuan untuk mengetahui apakah alokasi dana hibah bansos oleh pemerintah mempengaruhi elektabilitas calon incumbent pada waktu pra-pemilihan presiden 2019. Untuk Analisa penelitian dilakukan terhadap data sekunder berupa data APBN pada tahun pra-pemilihan presiden 2019 dengan tujuan untuk melihat trend alokasi anggaran Bansos mendekati tahun pemilihan presiden 2019. Kemudian data-data dari lembaga survey nasional untuk melihat tingkat elektabilitas calon kandidat pasangan peserta pemilihan presiden 2019. Sedangkan untuk penyajian data dilakukan dengan matrik, grafik, bagan, dan teks naratif dan penarikan untuk kesimpulan/verifikasi yang merupakan akhir dari analisis data dilakukan dengan pemaknaan melalui refleksi atas data hasil penelitian yang diperoleh (Gumilang, 2016).

\section{HASIL DAN PEMBAHASAN}

\section{Politisasi Anggaran Bantuan Sosial}

Politik anggaran tidak dapat dilepaskan dalam kaitannya dengan proses alokasi sumber 
daya keuangan di dalamnya. Perlu pemahaman bahwa politik sebagai arena alokasi dan distribusi sumber daya keuangan. Politik anggaran tidak bisa terlepas dari struktur kekuasaan atau dari para aktor politik, yang berkepentingan untuk dapat memertahankan kekuasaan mereka. Sebagai eksekutif, dominasi pemerintah dalam penganggaran didukung oleh seluruh jajaran struktur organisasi pemerintahan, yang memiliki keunggulan dalam hal pengalaman, pengetahuan, serta penguasaan terhadap seluruh fungsi pemerintahan. Dominasi kekuasaan pemerintah dan para aktor politik di DPR, sejak proses perencanaan hingga pelaksanaan anggaran, ditunjukkan dengan kemampuan mereka untuk memengaruhi dan menentukan keputusan (APBN). Relasi kekuasaan yang telah terbangun secara demokratis ini, diharapkan dapat diatur kembali dengan menjunjung tinggi prinsip-prinsip demokrasi di atas segalanya agar kesejahteraan rakyat menjadi utama demi mencapai kebaikan bersama dalam sebuah Negara. Idealnya sebuah anggaran harus besifat desentralisasi fiskal yang transparan, akuntabilitas baik untuk mengatur alokasi belanja pada program-program pemerintah yang berorientasi untuk mencapai kesejahteraan rakyat. Namun, seringkali terjadi penyerapan anggaran yang tidak optimal disebabkan oleh adanya tarik ulur kepentingan politik antara legislative dan eksekutif dalam penetapan anggaran (Rezeki \& Hasanuddin, 2017)democratic rights and freedom of expression have been key issues in discourses surrounding EU,ÄîTurkey relations. Discussions on these questions often centre on state censorship and legislative constraints. The role of the media themselves, however, and the deeply-ingrained elements and historically-contingent norms and practices within public culture that shape the public sphere, have received a significantly lower level of attention. Despite recent legislative changes towards greater freedom of expression, major hurdles that limit democratic rights and freedoms persist in practice, as highlighted by the judicial trial (and the subsequent murder in January 2007.

Dalam menetapkan besaran anggaran untuk alokasi dana bantuan sosial harus berpegang pada asas keadilan, kepatutan, rasionalitas, dan manfaat yang luas bagi masyarakat sehingga jauh dari kepentingan pribadi dan kelompok serta kepentingan politik. Meskipun demikian menjelang waktu pemilihan umum, besaran dalam penetapan alokasi untuk dana bantuan sosial rawan disalahgunakan untuk kepentingan politik. Berdasarkan Permendagri Nomor 21 Tahun 2011, yang merupakan perubahan kedua dari Permendagri Nomor 13 Tahun 2006, dijelaskan bahwa belanja hibah dan bantuan sosial ini masuk dalam kategori belanja tidak langsung sehingga dalam pengalokasiannya tidak didasarkan pada target kinerja tertentu dan penentuan alokasi besaran anggarannya cenderung bersifat subjektif yang tentunya ini sangat rentan untuk dipolitisasi. Pemanfaatan pada pengalokasian anggaran untuk program-program bantuan sosial dilakukan untuk kepentingan aktor-aktor politik karena sifat program tersebut yang populis, sehingga sering disalahgunakan untuk kepentingan politik dalam pemilihan umum. Politisasi pada anggaran bantuan sosial yang dapat dimanfaatkan sebagai dana publik disamarkan menjadi program populis yang memiliki dasar hukum dan bersifat legal. Akibatnya tidak mudah dituding sebagai penyalahgunaan kekuasaan eksekutif ataupun sebagai pelanggaran pemiihan umum.

Dalam hal ini, apabila kelompok eksekutif sebagai pemegang otoritas politik berfokus pada kepentingan untuk kemenangan dalam pemilihan umum, maka distribusi sumber daya anggaran melalui bantuan sosial tersebut dapat mengarah pada berbagai tindakan atau strategi untuk memenangkan pemilihan umum. Sehingga, secara eksplisit telah terjadi praktik penerapan politik distributif dengan pemanfaatan program pemerintah (program bantuan sosial) untuk meraih kemenangan pada saat kontestasi pemilihan umum. Oleh sebab itu, politik distribusif dalam penetapan alokasi anggaran untuk program-progam bantuan sosial dari pemerintah akan lebih cenderung menguntungkan calon incumbent dan juga partai penguasa dalam pemerintahan. Hal demikian dikarenakan seorang incumbent dan partai pemerintah kemungkinan memiliki kontrol secara lebih ekslusif dengan memanfaatkan keberhasilan program-program pemerintah sebagai konten politis dalam kampanye untuk meraih dukungan dari masyarakat pemilih pada saat pemilihan umum periode berikutnya. Meningkatnya besara alokasi dana bantuan sosial menunjukan adanya kepentingan politis dari petahana untuk menarik minat pemilih dalam pemilihan umum (Habibi, 2018).

\section{Politik Pork Barrel Dalam Alokasi Dana Bantuan Sosial}

Setiap proses pembahasan anggaran selalu terjadi dinamika politik antara eksekutif dan legislative yang tidak bisa dilepaskan dari kepentingan politik para elit maupun penguasa (N. L. L. Aziz, 2016; Zulfikar \& Effendi, 2018). Dalam perspective anggaran, politik dilihat sebagai arena alokasi dan distribusi sumber daya. Dapat diartikan politik adalah segala sesuatu yang dapat memberdayakan warga dalam relasi kuasa terhadap pihak lain. Keterkaitan dengan pengalokasian besaran dana bantuan sosial sebagai sumber daya anggaran yang dialokasikan serta didistribusikan kepada masyarakat luas dalam relasi 
kuasanya terhadap pihak lain, khususnya presiden yang diposisikan sebagai calon petahana. Distribusi sumber daya dalam politik anggaran bantuan sosial tidak dapat dilepaskan dari upaya politik seorang petahana untuk meraih kemenangan kembali pada pemilihan umum berikutnya. Hal ini identik dengan fenomena politik yang disebut Pork Barrel yang dalam penelitian ini diartikan sebagai suatu upaya politis dari calon incumbent melalui pengalokasian anggaran pada program-program pemerintah pusat kepada daerah dengan tujuan meningkatkan elektabilitas pada pemilihan periode berikutnya.

Dalam setiap kontestasi pemilihan umum, kandidat petahana memiliki akses yang luas terhadap penentuan alokasi anggaran sehingga mempunyai nilai pengaruh yang tinggi terhadap konstituen. Semakin besar akses yang dimiliki terhadap pengaturan alokasi sumber daya keuangan negara dan didukung mayoritas kekuatan politik serta memiliki popularitas yang baik di masyarakat akan menjadi modal besar yang dapat dimanfaatkan oleh calon kandidat petahana sebagai salah satu strategi politik untuk menaikkan elektabilitasnya. Di Indonesia, alokasi pada program-program bantuan sosial merupakan senjata untuk peningkatan elektablitas calon incumbent dalam menghadapi pemilihan umum. Adapun tren dari besaran alokasi untuk program bantuan sosial mendekati tahun 2019 sebagai tahun politik di Indonesia seperti pada tabel berikut.

Tabel 1. Alokasi Pengunaan Dana Bantuan Sosial Pada Program Sosial Pemerintah

\begin{tabular}{lrrrc}
\hline \multirow{2}{*}{$\begin{array}{l}\text { Program Sosial } \\
\text { Pemerintah }\end{array}$} & \multicolumn{4}{c}{ APBN (dalam milyar rupiah) } \\
\cline { 2 - 5 } & $\mathbf{2 0 1 5}$ & $\mathbf{2 0 1 6}$ & $\mathbf{2 0 1 7}$ & $\mathbf{2 0 1 8}$ \\
\hline $\begin{array}{l}\text { Program } \\
\text { Rehabilitasi } \\
\text { Sosial }\end{array}$ & $1.692,1$ & $1.197,4$ & 926,2 & $1.006,5$ \\
$\begin{array}{l}\text { Program } \\
\text { Perlindungan Dan } \\
\text { Jaminan Sosial }\end{array}$ & $16.739,8$ & $9.307,6$ & $13.169,6$ & $17.671,4$ \\
\hline Total & & & & \\
\hline & $18.431,9$ & $10.505,0$ & $14.095,8$ & $18.677,9$ \\
\hline & & \multicolumn{3}{c}{ Sumber: Data APBN, 2015-2018 }
\end{tabular}

Berdasarkan pada tabel 1 tersebut dapat diketahui besaran alokasi dana bantuan sosial yang digunakan melalui program sosial dari pasca pemilu presiden 2014 sampai menjelang pemilihan presiden di tahun 2019. Pasca pemilihan presiden 2014, besaran alokasi anggaran untuk bantuan sosial yang dilaksanakan oleh pemerintah melalui Program Rehabilitasi Sosial dan Program Perlindungan Jaminan Sosial mengalami penurunan 43,03\% dari 18,43 milyar rupiah di tahun 2015 menjadi 10,5 milyar rupiah pada tahun 2016. Setelah itu, kembali mengalami peningkatan sebesar 34,19\% di tahun 2017 menjadi 14,09 milyar rupiah dan semakin meningkat lagi 32,5\% pada 2018 dengan besaran 18,67 milyar rupiah. Terjadinya penurunan dana bansos tersebut dilakukan karena adanya reklasifikasi anggaran dari beberapa kementerian seperti di Kementerian PUPR untuk belanja barang, di Kemendikbud untuk tunjangan guru. Namun, bansos kembali dinaikkan lagi mendekati waktu pemilihan presiden oleh pemerintah, dan hal tersebut wajar dilakukan sebagai bagian yang digunakan oleh petahana untuk kepentingan elektoralnya di periode pemilihan beikutnya. Hal tersebut menjadi peluang petahana untuk lebih meningkatkan citra diri mendekati pelaksanaan pemilihan umum (Setiawan \& Setyorini, 2018).

Melihat perkembangan dari besaran alokasi anggaran bantuan sosial melalui Program Rehabilitasi Sosial dan Program Perlindungan Jaminan Sosial mengalami penurunan pasca pemilihan presiden 2014, kemudian mendekati tahun politik 2019 kembali meningkat menandakan adanya indikasi dari seorang incumbent untuk menjaga elektabilitasnya agar tetap tinggi sebelum mencalonkan sebagai kandidat presiden pada pemilihan presiden tahun 2019. Dengan elektabilitas yang kuat tentu akan lebih dikenal oleh masyarakat pemilih sehingga menjadi modal awal bagi seorang kandidat yang akan berkontestasi lagi pada pemilihan umum berikutnya. Besar kecilnya alokasi anggaran yang ditetapkan oleh pemerintah melalui program sosial hingga mendekati waktu pelaksanaan pemilihan presiden 2019 tersebut memberikan sinyal adanya motif kepentingan politik. Upaya meningkatkan anggaran bantuan sosial menjelang pelaksanaan pemilihan untuk menarik simpati melalui program bantuan sosial sekaligus kampanye secara terselubung merupakan salah satu modus politis (Wulandari, 2012).

Kandidat yang diposisikan sebagai incumbent dengan segala bentuk kuasa eksekutifnya memang memiliki keunggulan dalam mengintervensi besaran penetapan dalam distribusi anggaran untuk programprogram pemerintah. Keuntungan dari calon petahana tentu memiliki kekuasaan yang lebih dalam mengalokasikan sumber daya anggaran. Penguasa yaitu incumbent memiliki keunggulan karena memiliki akses terhadap sumber daya yang dananya berasal dari pemerintahan, sertalebihdekatpadamasyarakatkarena pemerintah berinteraksi langsung dengan masyarakat sekaligus sebagai eksekutor dalam program-program pemerintahan. Selain itu juga merupakan aktor yang melakukan transaksi langsung dengan masyarakat. Hal itu tentu saja menjadi keuntungan bagi seorang petahana karena secara tidak langsung menjadi lebih dikenal masyarakat dan juga memiliki kewenangan dalam pendistribusian sumber daya. Calon petahana memiliki peluang yang cukup besar 
untuk mempengaruhi besaran anggaran pada pos-pos belanja pemerintah melalui mekanisme penyusunan APBN dalam memenuhi kepentingan politisnya guna mencalonkan kembali pada pemilihan berikutnya. Pospos belanja pemerintah yang berhubungan langsung dengan masyarakat seperti anggaran bantuan sosial menjadi sasaran utama yang dapat dimanfaatkan oleh incumbent sebagai sarana untuk berpolitik. Alokasi pada pos belanja ini digunakan sebagai sarana untuk memikat hati dan juga mendapatkan simpati masyarakat agar memilih dirinya kembali dalam pemilihan umum periode berikutnya. Jokowi sebagai calon presiden petahana pada pemilihan presiden periode 2019diduga memanfaatkan pendistribusian anggaran bantuan untuk mendongkrak elektabilitasnya sebelum pelaksanaan pemilihan. Adapun untuk trend besaran belanja bantuan sosial di era Presiden Jokowi mendekati kontestasi pemilihan presiden 2019 dapat dilihat pada gambar berikut.

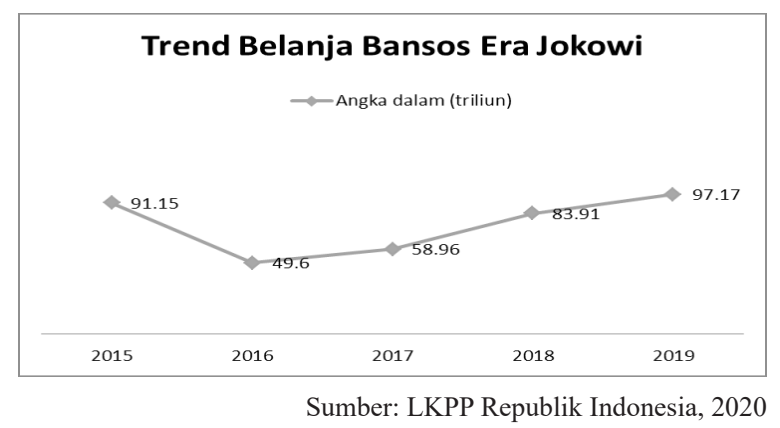

Gambar 1. Grafik Perkembangan Besaran Belanja Bansos di Era Presiden Jokowi

Berdasarkan gambar 1. menunjukkan trend belanja bantuan sosial di era pemerintahan Presiden Joko Widodo. Setelah terplilih dalam pemilihan umum tahun 2014 trend belanja bantuan sosial pada tahun 2015 - 2016 penurunan tajam (46,18\%) dari 91,15 Triliun menjadi 49,06 Triliun. Hal ini bukan suatu rahasia dimana pada masa pemerintahan Presiden Joko Widodo yang pertama ini lebih difokuskan kepada pembangunan Infrastruktur dibandingkan pembangunan Sumber Daya Manusia. Akan tetapi seiring pembangunan infrastruktur yang sangat luar biasa presiden Jokowi kemudian juga meningkatkan belanja bansos secara bertahap dari tahun 2017 sebesar 58,96 Triliun menjadi 83,91 Triliun pada 2018 atau meningkat 42,32\%. Trend kenaikan belanja bansos mendekati tahun 2019 sebagai tahun politik menjadi 97,17 Triliun (naik 15,80\%) menjadi indikasi adanya kepentingan politik yang dilakukan oleh Presiden Joko Widodo sebagai seorang petahana untuk memperoleh dukungan kembali konstituennya pada pelaksanaan pemilihan umum tahun 2019. Belanja bantuan sosial dimanfaatkan oleh incumbent agar menarik minat pemilih dalam pemilihan umum merupakan kepentingan politis (Habibi, 2018).
Pola meningkatkan alokasi dana bansos mendekati pelaksanaan pemilihan presiden sama dengan yang dilakukan pada era pemerintahan SBY. Berdasarkan dari data LKPP Republik Indonesia, dari kurun waktu tahun 2008 hingga 2014 tren belanja bansos di Era presiden Susilo Bambang Yudhoyono mengalami trend peningkatan. Tahun 2008 pemerintah memberikan alokasi bansos hanya sebesar 57,74 Triliun yang digunakan untuk kompensasi BBM (3,85 Triliun) dan bantuan langsung sekolah (28,09 Triliun). Menjelang pilpres tahun 2009, alokasi dana bansos oleh SBY sebagai calon petahana dinaikan menjadi 73, 81 Triliun. Setelah terpilih kembali pada periode kedua, SBY sempat menurunkan alokasi bansos menjadi 68,61 Triliun, namun kembali cenderung meningkat menjadi 92 Triliun pada 2013 dan meningkat kembali menjadi 97,94 Triliun pada 2014 sebagai tahun politik. Pada tahun 2014 yang menjadi akhir periode kedua pemerintahan SBY juga mulai menyalurkan Bantuan Langsung Sementara Masyarakat (BLSM) sebagai kompensasi kenaikan harga BBM.

Mendekati tahun politik (2009 dan 2014), alokasi dana bansos memiliki trend kenaikan. SBY sebagai petahana meningkatkan alokasi bansos sebesar 27,90\% pada 2009, dan diakhir masa jabatannya pada tahun 2014 juga meningkatkan dana bansos tetapi hanya sebesar 6,46\%. Meskipun tidak signifikan, kenaikan dana bansos di penghujung masa jabatannya tersebut seakan menandakan bahwa presiden SBY merupakan presiden yang peduli dengan rakyat. Penggunaan dana Bansos pra pemilu di Indonesia pada masa Presiden SBY menjadi salah satu cara yang digunakan untuk meraih simpati masyarakat dan meningkatkan elektablitasnya.

Kenaikan anggaran bantuan sosial yang cukup signifikan pada APBN 2019 mengulang pola lama yang terjadi pada masa-masa menjelang tahun politik era sebelumnya, terjadi pada 2009 dan 2014. Pemerintah bisa saja mengelak soal kenaikan dana bantuan sosial bertujuan untuk kepentingan elektoral. Namun, rekam catatan anggaran bantuan sosial menjelang Pemilu pada masa lalu jadi buktinya, hanya berbeda nama dan pendekatan saja dengan modifikasi oleh pemerintah (Gusman, 2020). Jika di masa SBY pendekatan dalam penggunaan bansos disalurkan secara tunai untuk kompensasi kenaikan BBM dengan bentuk BLT, di masa Jokowi dana bansos disalurkan secara non-tunai dengan harapan agar transparan dan akuntabel.

Bansos sebagai program populis dari pemerintah menjadi salah satu isu strategis yang bisa dimanfaatkan oleh calon incumbent dalam memperoleh suara pada penyelenggaraan pemilu periode berikutnya. Dengan menaikan alokasi dana pada program bansos secara tidak langsung dapat 
mendongkrak citra yang baik calon incumbent dimata konstituen. Citra ini diharapkan dapat menarik simpati publik untuk memilihnya kembali pada kontestasi pemilihan, serta untuk menjaga elektabilitas incumbent tetap tinggi. Sebagai salah satu alat petahana untuk memperoleh simpati publik dalam mendongkrak suara serta nilai elektabilitas maka bansos menjadi penting untuk dimanfaatkan petahana dalam meningkatkan perolehan suara pemilu. Program pemerintah yang populis menjadi kesempatan yang bisa digunakan oleh petahana sebagai sarana menaikkan tingkat keterpilihan atau mempertahankan suara dalam pemilihan (Saragintan \& Hidayat, 2016).

Berdasar pada data-data mengenai alokasi untuk dana program sosial dan belanja sosial pemerintah yang terus mengalami kenaikan mendekati waktu pra-pemilihan presiden 2019, penulis mengidentifikasi bahwa memang pemberian bantuan sosial pada era pemerintahan Jokowi merupakan transaksi non-programa yang bersifat politik Pork Barrel. Jika dianalisa menggunakan karaketristik politik Pork Barrel, alokasi anggaran untuk bantuan sosial pada masa pemerintahan Jokowi memenuhi ciri--ciri tersebut. Pertama, praktik alokasi dalam penetapan besaran bantuan sosial ini dilakukan oleh incumbent, yaitu Presiden Joko Widodo yang bisa dinilai mendorong distribusi dana bantuan sosial untuk kepentingan pemenangan dalam pemilihan presiden 2019 sebagai periode keduanya. Kedua, alokasi ini menggunakan anggaran yang bersumber dari negara yakni dari penerimaan yang tidak berbasis kewilayahan. Artinya, alokasi khusus tersebut menjadi tanggungan dari dana publik secara umum, baik melalui dana pusat maupun penerimaan pajak daerah. Ketiga, besaran alokasi dana tersebut mayoritas berasal dari inisiatif eksekutif. Dilihat dari pola penerimaannya mengindikasikan bahwa pemberian bantuan sosial bersifat group targeted. Artinya, alokasi anggaran bantuan sosial bukan digunakan untuk kepentingan individu, Hal itu pun sudah pasti ditargetkan oleh incumbent dan bersifat "top down" dari level pemerintah pusat ke level pemerintahan daerah. Karakteristik terakhir ialah peningkatan alokasi anggaran bantuan sosial mengalami peningkatan dan terjadi sebelum penyelenggaran pemilihan presiden tahun 2019 sehingga tidak bersifat mengikat konstituen penerima untuk memilih incumbent. Dalam politik Pork Barrel, transaksi politik distributif anggaran ini dilakukan pada waktu pra-pemilihan sehingga sumber daya anggaran bantuan tersebut diberikan sebelum dilaksanakannya pemilihan umum tahun 2019. Berdasarkan karaketristik atau indikator yang ada, praktik alokasi besaran dana untuk bantuan sosial di era pemerintahan Joko Widodo dapat dikatakan sebagai bentuk atau fenomena politik Pork Barrel di Indonesia, karena ciri-ciri tersebut memang mendekati karakteristik dari konsep politik Pork Barrel. Menjelang tahun politik, alokasi penetapan anggaran bantuan sosial rawan untuk disalahgunakan sebagai komoditas politik pada waktu prapemilihan. Peran anggota dewan sebagai control atas pengawasan anggaran pemerintah perlu didukung dengan pengetahuan dewan terkait anggaran (Dewi, Nuraina, \& Murwani, 2018).

\section{Meningkatkan Elektabilitas Melalui Politik Anggaran}

Secara umum, persoalan mengenai anggaran publik adalah persoalan yang berkaitan erat dengan kepentingan politik. Proses perencanaan dan penetapan alokasi anggaran menjadi tempat kontestasi bagi aktor penguasa dan para elit negara untuk mencapai berbagai macam kepentingannya. Politik anggaran merupakan suatu proses kekuasaan politik di antara berbagai kepentingan yang terlibat dalam penentuan kebijakan dan alokasi anggaran (N. L. L. Aziz, 2016). Dalam konteks politik, APBN adalah suatu dokumen politik dari kesepakatan antara legislatif (DPR) dengan eksekutif (Presiden). Mendekati waktu palaksanaan pemilihan umum, politisasi anggaran merupakan fenomena yang sudah lazim dilakukan oleh elit penguasa dalam rangka mencapai kepentingan politiknya. Melalui penetapan alokasi anggaran yang lebih pro-rakyat akan membentuk persepsi publik bahwa pemerintah memiliki kepedulian dan tanggung jawab yang tinggi untuk benar-benar mewujudkan kesejahteraan rakyat. Bantuan sosial sebagai kebijakan dan program yang tidak berbasis pada target kinerja tertentu rawan dipolitisasi karena dalam proses penetapan besaran alokasi anggarannya cenderung bersifat subjektif. Hal tersebut sering dimanfaatkan untuk kepentingan para elit penguasa karena program tersebut bersifat populis, sehingga sering disalahgunakan mendekati tahun pemilu. Narasi politik yang dibangun kandidat petahana melalui politik anggaran bantuan sosial yang pro-rakyat seperti ini akan menciptakan citra yang baik di mata publik, sehingga dapat meningkatkan elektabilitasincumbent apabilakembali mencalonkan diri pada pemilihan berikutnya. Politisi yang sedang berkuasa memiliki motivasi untuk kembali berkuasa dan kemudian melakukan berbagai cara untuk meningkatkan keterpilihannya kembali melalui instrument anggaran seperti mengubah alokasi anggaran (Rahman, 2018). Adapun hasil survei elektabilitas dari kandidat pasangan calon presiden dan wakil presiden peserta pemilihan presiden periode 2019 adalah sebagai berikut. 


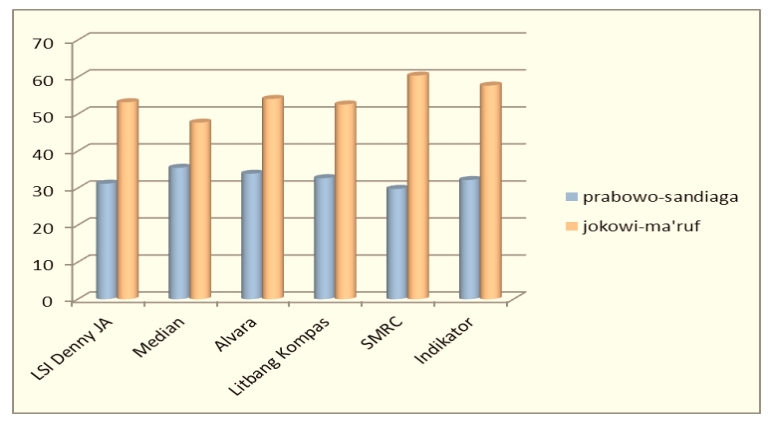

Sumber: Berbagai Lembaga Survei, 2018

Gambar 2. Survei Elektabilitas Pemilihan Presiden 2019

Berdasarkan pada gambar 2. dapat dilihat tingkat elektabilitas pasangan Jokowi-KH. Maruf Amin lebih unggul daripada pasangan PrabowoSandi mendekati waktu pemilihan presiden 2019. Pada masa pra-pemilihan presiden 2019, elektabilitas Jokowi memiliki kecenderungan lebih stabil pada anggka sekitar 50-60\%, sedangkan Prabowo Subianto elektabilitasnya masih dibawah Jokowi dan berada pada angka 30-35\%. Tingginya elektabilitas dari Jokowi menjelang pemilihan presiden 2019 sesuai dengan trend meningkatnya alokasi besaran anggaran belanja sosial [lihat gambar 1] dan program bantuan sosial [lihat tabel 1] dalam penelitian ini. Melihat terjadinya peningkatan alokasi anggaran untuk bantuan sosial mendekati pelaksanaan pemilihan presiden, diidentifikasikan bahwa program tersebut merupakan salah satu cara untuk meningkatkan elektabilitas Presiden Jokowi pada saat pemilihan presiden 2019. Penggunaan dana bansos yang dalam distribusinya bisa dikatakan lebih cepat dan dilakukan sebelum pemilihan umum merupakan salah satu strategi politik yang dilakukan Presiden Jokowi. Sifat program yang menyuluruh dan sampai kepada masyarakat yang paling bawah tentu menjadi satu nilai lebih yang dimiliki pasangan petahana dibandingkan kandidat kompetitornya dalam pelaksanaan kontestasi pemilihan umum. Setelah dana bantuan didistribusikan, elektabilitas Presiden Jokowi yang pada waktu itu berpasangan dengan KH. Maruf Amin perlahan meningkat melebihi calon presiden Prabowo Subianto dan Sandiaga Uno. Persepi masyarakat yang menyatakan bahwa Presiden Jokowi merupakan presiden yang peduli dengan masyarakat merupakan nilai positif pada dirinya. Tentu persepsi masyarakat tersebut didasarkan atas penetapan anggaran untuk alokasi pada bantuan-bantuan atau program sosial yang dilakukan oleh pemerintahan Presiden Jokowi kepada masyarakat seluruhnya tersampaikan secara baik. Maka inilah yang menjadi sorotan di Indonesiaa saat ini dan beberapa periode kebelakang dimana trend belanja bantuan sosial atau penganggaran dana bantuan sosial selalu dimainkan untuk kepentingan politis karena sifatnya yang populis. Tentu, hal tersebut dapat mengganggu kinerja pemerintah karena dalam penetapan kebijakan anggaran lebih diutamakan untuk memenuhi tuntutan politik, adanya pergeseran relasi kekuasaan serta adanya kontrol kepemilikan kepentingan politik (Hastuti, 2018).

\section{SIMPULAN}

Berdasarkan pada hasil analisis dan pembahasan dapat disimpulkan besaran alokasi penganggaran untuk bantuan sosial dilakukan pemerintah mengalami peningkatan sebesar 42,32\% mendekati pemilihan presiden tahun 2019. Trend kenaikan belanja bantuan sosial tersebut menjadi indikasi adanya kepentingan politik yang dilakukan oleh calon petahana untuk memperoleh dukungan kembali konstituennya pada pelaksanaan pemilihan umum tahun 2019. Alokasi besaran pada belanja bantuan sosial dimanfaatkan oleh incumbent agar menarik minat konstituennya dan meningkatkan elektabilitas petahanan dalam kontestasi pemilihan umum. Penetapan besaran alokasi anggaran bansos oleh pemerintah mempengaruhi elektabilitas calon incumbent pada waktu pra-pemilihan presiden. Meningkatnya alokasi besaran anggaran bantuan sosial menjelang pemilihan presiden 2019 berbanding lurus dengan tingginya elektabilitas dari Jokowi sebagai kandidat petahana. Ini menjadi salah satu indikasi bahwa program tersebut merupakan salah satu cara untuk meningkatkan elektabilitas Presiden Jokowi menjelang pemilihan presiden 2019. Anggaran bantuan sosial dari pemerintah dapat dikatakan sebagai salah satu bentuk politik Pork Barreldi Indonesia. Hal ini dikarenakan bantuan sosial dijadikan sebagai suatu upaya politis dari calon incumbent melalui pengalokasian anggaran dalam program-program pemerintah pusat kepada daerah dengan tujuan meningkatkan elektabilitas pada pemilihan berikutnya. Sehingga, politik anggaran pada bantuan sosial menjadi salah satu isu strategis yang dapat dimanfaatkan oleh setiap kandidat petahana untuk meningkatkan elektabilitasnya pada periode pemilihan berikutnya.

\section{DAFTAR PUSTAKA}

Aziz,A. (2019). Mewaspadai Lonjakan Dana Bansos Jelang Pilpres 2019. Tirto.Id. Retrieved from https://tirto.id/mewaspadai-lonjakan-danabansos-jelang-pilpres-2019-dhv1

Aziz, N. L. L. (2016). Politik Anggaran Dalam Pelaksanaan Pilkada Serentak Di Indonesia. Masyarakat Indonesia, 42(1), 51-64.

Denemark, D. (2000). Partisan Pork Barrel in Parliamentary Systems: Australian Constituency-Level Grants. The Journal of Politics, 62(3), 896-915. 
Dewi, W. M., Nuraina, E., \& Murwani, J. (2018). Pengaruh Personal, Politik Background, Pengetahuan Anggaran Terhadap Peran Dewan Dalam Pengawasan Keuangan Daerah. Forum Pendidikan Ilmiah Akutansi (FIPA), 6(2). Retrieved from http://prosiding. unipma.ac.id/index.php/FIPA/article/ view/557

Farida,A.(2019). Studi Pustaka tentang Perkembangan Teknologi dan Peningkatan Kepatuhan Pajak: Apakah Berbanding Lurus? Moneter - Jurnal Akuntansi dan Keuangan, 6(2), 135-140. https://doi.org/10.31294/moneter.v6i2.6183

Golden, M., \& Min, B. (2013). Distributive Politics around the World. Annual Reviews of Political Science, 16, 73-99.

Gumilang, G. S. (2016). Metode Penelitian Kualitatif Dalam Bidang Bimbingan Dan Konseling. Jurnal Fokus Konseling, 2(2), 144-159.

Habibi, M. (2018). Politik Discretionary Fund Anggaran Pendapatan Dan Belanja Daerah Sebelum Dan Padasaat Pemilukada Tahun 2015 Di Kota Samarinda. Prosiding Konferensi Nasional Ke- 8 Asosiasi Program Pascasarjana Perguruan Tinggi Muhammadiyah (APPPTMA), 1-6.

Habibi, M., Kalalinggi, R., \& Alaydrus, A. (2018). Politik Anggaran Belanja Hibah Dan Belanja Bantuan Sosial Calon Kepala Daerah Incumbent Dalam Pemilihan Umum Kepala Daerah Tahun 2015 Di Kota Samarinda. Jurnal Ilmu Pemerintahan, 6(1), 269-282.

Hastuti, P. (2018). Desentralisasi Fiskal Dan Stabilitas Politik Dalam Kerangka Pelaksanaan Otonomi Daerah Di Indonesia. Simposium Nasional Keuangan Negara, 784-799.

Hessami, Z. (2014). Electoral Rules for Mayors and Incentives to Pork-Barrel:Quasi-Experimental Evidence from German Municipalities. Collective Decision Making II, No. B06-V3, German Economic Association 2014.

Laksono, F. (2017). Dimensi Manajerial dan Politik Proses Penyusunan dan Penetapan Anggaran Pendapatan dan Belanja Daerah (Studi Ketepatan Waktu Proses Penyusunan dan Penetapan Anggaran Pendapatan dan Belanja Daerah Kabupaten Blitar Tahun Anggaran 2013 -2015). Jurnal Ilmiah Administrasi Publik, 3(1), 28-35. https://doi.org/10.21776/ ub.jiap.2017.003.01.4

Mentang, F. J., Sabijono, H., \& Pangerapan, S. (2020). Analisis Penyusunan Anggaran
Dan Realisasi Belanja Daerah Pada Badan Perencanaan Penelitian Dan Pengembangan Daerah Kota Manado. Jurnal Riset Akuntansi, 15(2), 131-138.

Moleong, L. J. (2012). Metodologi Penelitian Kualitatif. Bandung: PT. Remaja Rosdakarya.

Murhaban, \& Munandar, A. (2019). Pengaruh Pendapatan Sendiri, Jenis Pemerintah Daerah Dan Letak Pemerintah Daerah Terhadap Perilaku Oportunistik Legislatif Di Dewan Perwakilan Rakyat Kabupaten Aceh Utara. Jurnal Akuntansi Dan Keuangan Penganggaran, 7(2), 135-148.

Nugraheni, R. Y., \& Hidayat, Z. (2018). Evaluasi Pengelolaan Keuangan Pemerintah Daerah Kota Semarang. Journal Of Public Policy And Management Review, 7(1), 1-14. https:// doi.org/DOI: 10.14710/jppmr.v7i1.19130

Purwanto, A. (2016). Pengaruh Kondisi Keuangan Dan Politik Terhadap Perubahan Anggaran Pada Pemerintah Daerah Di Indonesia. Jurnal Akuntansi Dan Bisnis, 16(2), 87-96. https:// doi.org/10.20961/jab.v16i2.198

Rahman. (2018). Pendapatan Daerah dan Siklus Politik Kabupaten/Kota di Indonesia. Jurnal EKOBISTEK, 7(1), 59-67.

Ramadhani, R., \& Setiawan, M. A. (2019). Pengaruh Regulasi, Politik Anggaran, Perencanaan Anggaran, Sumber Daya Manusia Dan Pengadaan Barang/ Jasa Terhadap Penyerapan Anggaran Belanja Pada Opd Provinsi Sumatera Barat. Jurnal Eksplorasi Akuntansi, 1(2), 710-726.

Rezeki, N. S., \& Hasanuddin. (2017). Desentralisasi Fiskal: Studi Tentang Pemerintah Kota Pekanbaru Dalam Penyerapan Anggaran Pendapatan Dan Belanja Daerah (Apbd) Tahun 2014. JOM FISIP, 4(1), 1-17. https:// doi.org/10.1177/1742766510373715

Saragintan, A., \& Hidayat, S. (2016). Politik Pork Barrel di Indonesia: Kasus Hibah dan Bantuan Sosial di Provinsi Banten tahun 2011. Jurnal Politik, 2(1), 137-163. https://doi.org/DOI: https://doi.org/10.7454/jp.v2i1.85

Setiawan, D., \& Setyorini, E. (2018). Dampak Pemilihan Kepala Daerah terhadap Alokasi Belanja Daerah. Kajian Ekonomi Dan Keuangan, 2(2), 106-119. https://doi. org/10.31685/kek.v2i2.365

Solihah, R. (2016). Politik Transaksional Dalam Pilkada Serentak Dan Implikasinya Bagi Pemerintahan Daerah Di Indonesia. The 
POLITICS: Jurnal Magister Ilmu Politik Universitas Hasanuddin, 2(1), 97-109.

Tessa, S. (2018). Pengaruh Regulasi Keuangan Daerah, Politik Anggaran Dan Pelaksanaan Pengadaan Barang/Jasa Terhadap Penyerapan Anggaran Pada OPD Provinsi Sumatera Barat. Jurnal Akuntansi, 5(3), 1-12. Retrieved from http://ejournal.unp.ac.id/students/index. php/akt/article/view/3804

tirto.id. (2019). Mewaspadai Lonjakan Dana Bansos Jelang Pilpres 2019. Retrieved from https:// tirto.id/mewaspadai-lonjakan-dana-bansosjelang-pilpres-2019-dhv1

Wance, M. (2019). Dinamika Perencanaan Anggaran Pada Anggaran Pendapatan Belanja Daerah (APBD) Buru Selatan. The Indonesian Journal of Public Administration, 5(1), 1-17.
Retrieved from http://journal.uta45jakarta. ac.id/index.php/admpublik/index

Wilk, E. M. (2010). Ideology and Distributive Benefits: Ideological and District Influences on The Distribution of Federal Spending. New York: Disertasi University at Buffalo.

Wulandari, L. (2012). Dana Kampanye Pemilu di Indonesia: Isu Krusial yang Cenderung Terabaikan. Jurnal Pemilu \& Demokrasi, 3(3), 55-78.

Zulfikar, \& Effendi, H. (2018). Politik Pengelolaan Keuangan Negara (Studi Penyebab Keterlambatan Pengesahan APBA Tahun 2016). Jurnal Ilmiah Mahasiswa FISIP Unsyiah, 3(2), 181-191. Retrieved from www.jim.unsyiah.ac.id/FISIP 